\section{Лариса Владиченко}

Мусульманські організацій

В контексті державноконфесійних та міжконфесійних відносин 6 Украӥні

Анотація. В статті виокремлюються актуальні питання присутності мусульманських організацій в релігійному полі України: спрощення реєстраційної процедури статутів релігійних організацій та набуття ними статусу юридичної особи; реституційні питання (повернення культових споруд релігійним організаціям); створення інституційних структур військового капеланства в структурах Збройних сил України; об'єктивне ставлення до релігійних організацій та толерантний міжконфесійний дискурс; співпраця в соціальній сфері 3 релігійними організаціями; фотографування на документи представникам релігійних організацій; організаційні питання щодо здійснення хаджу; забезпечення права на релігійну свободу на анексованих та окупованих територіях України. На основі докладного аналізу статистики релігійних організацій та щорічних матеріалів опитування Центру Разумкова робиться висновок про загалом сприятливі умови для всіх громадян у праві на сповідування своєі релігії, у захищеності цього права законодавством України, діяльністю відповідних державних органів влади. Такими ж свободами і правами користуються і мусульмани та їх релігійні організації, яким потрібно більш активно долучатися до вирішення актуальних і проблемних питань у сфері відносин між державою та релігійними організаціями.

Ключові слова: іслам, мусульманські організації, державно-церковні відносини, міжконфесійні взаємини.

\section{Larysa Vladychenko}

\section{Muslim organizations in the context of state-denominational and inter-denominational relations in Ukraine}

Summary.The article highlights the pressing issues of the presence of Muslim organizations in the religious field of Ukraine: simplification of the registration procedure of the statutes of religious organizations and their acquisition of the status of a legal entity; restitutionary issues (returning religious buildings to religious organizations); creation of institutional structures of military chaplaincy within the structures of the Armed Forces of Ukraine objective attitude to religious organizations and tolerant interfaith discourse; cooperation in the social sphere with religious organizations; photographing on documents to representatives of religious organizations; organizational issues related to Hajj; securing the right to religious freedom in the annexed and occupied territories of Ukraine. On the basis of a detailed analysis of the statistics of religious organizations and the annual survey materials of the Razumkov Center, it is concluded that generally favorable conditions for all citizens in the right to profess their religion, in the protection of this right by the legislation of Ukraine, the activity of relevant state authorities. Muslims and their religious organizations enjoy the same freedoms and rights, which need to be more 
actively involved in resolving topical and problematic issues in relations between the state and religious organizations.

Key words: Islam, Muslim organizations, state-church relations, inter-denominational relations.

\section{Постановка проблеми. Проблематика} державно-конфесійних відносин в Україні $\epsilon$ достатньо актуальною як в сьогоденні, так i впродовж всього періоду незалежності України. Україна є полірелігійною та поліконфесійною країною. У зв'язку із чим кожний конфесійний напрям характеризується множинністю релігійних організацій. В цьому контексті слід також відзначити відсутність організаційної єдності і єдиної структури управління мусульманських організацій в Україні. Держава і суспільство мають знати про ситуацію всередині кожного конфесійного напрямку, зміни, які там відбуваються, тенденції, які характеризують ці зміни, щоб вчасно корегувати свою політику в сфері державно-конфесійних відносин.

Відповідно і суспільство, особливо громадянське, яке не байдуже до процесів, які протікають в ньому, зацікавлене в об'єктивній інформації щодо стану i розвитку такої релігії, як іслам в нашій країні, його взаємин із іншими релігіями, що працюватиме на свободу віросповідання і толерантність міжрелігійних відносин.

Заявлена проблематика ніколи не випадала із кола уваги державних органів влади, які при визначенні державної стратегії щодо ісламу завжди спиралися на дослідження вітчизняних вчених О.Ауліна, Д.Брильова, С.Ісмагілова, М. Якубовича, О. Яроша та ін., які всебічно вивчають іслам [Брильов 2011; Якубович 2018 тощо].
Безцінну допомогу надає Експертна рада 3 питань свободи совісті при Міністерстві культури України та сучасні дослідження ісламу в Україні [Мусульманська 2016; Ісламська 2915].

Виходячи 3 потреби постійно тримати руку на пульсі релігійного життя країни, метою даної статті $\epsilon$ аналіз сучасної релігійної ситуації, яка стрімко змінюється, що фіксується статистикою та опитуваннями, зосередившись на мусульманському сегменті, який має свої особливості. Подання об'єктивної картини щодо стану мусульман в Україні та виокремлення реальних проблем, з якими стикаються мусульманські громади, сприятиме налагодженню партнерських державно-церковних і міжрелігійних відносин.

Виклад основного матеріалу. Серед актуальних питань в сфері державноконфесійних відносин в Україні, які найчастіше обговорюються в цій сфері, 30крема і в контексті діяльності мусульманських організацій, назвемо наступні: спрощення реєстраційної процедури статутів релігійних організацій та набуття ними статусу юридичної особи; реституційні питання (повернення культових споруд релігійним організаціям); створення інституційних структур військового капеланства в структурах Збройних сил України; об'єктивне ставлення до релігійних організацій та толерантний міжконфесійний дискурс; співпраця в соціальній сфері $з$ релігійними організаціями; фотографування на документи представникам релігійних організацій; організаційні питання щодо здійснення хаджу; забезпечення права на релігійну свободу на 
анексованих та окупованих територіях України.

В Україні на 1 січня 2019 р. проводять свою діяльність 36739 інституцій релігійних організацій. За двадцять сім років незалежності України релігійна мережа держави збілышилася в 2,8 рази.

Не дивлячись на високу конкурентність у відносинах між релігійними організаціями, українське суспільство толерантне в питаннях віросповідання, що засвідчують результати соціологічних опитувань. Наприклад, результати соціологічного дослідження «Релігія і церква в українському суспільств», проведеного Соціологічною службою Центра Разумкова у 2018 році, показують, що 74\% респондентів підтримали думку, що будьяка релігія, яка проголошує ідеали добра, любові, милосердя і не загрожує існуванню іншої людини, має право на існування; $19 \%$ - право на існування мають тільки традищійні для нашої країни віросповідання, а лише 5\% зазначили, що істинна тільки та релігія, яку я сповідую [Особливості 2018: 20].

Іслам на початок 2019 року представлений в Україні 277 релігійними осередками, які складають $0,75 \%$ релігійноінституційної мережі держави [Звіт 2019b: 57-59]. Зауважимо, що державна статистика інституційної мережі релігійних організацій з 2015 року наводиться без врахування показників мережі релігійних організацій АР Крим (оскільки остання є анексованою, а частина Донецької та Луганської областей окупована), оскільки релігійні організації на цих територіях позбавлені можливості діяти згідно норм українського законодавства. Нагадаємо, що у 2014 році, до анексії Автономної Республіки Крим, в Україні діяло 1238 мусульманських структур, 3 яких 81\% складали саме релігійні організації мусульман Криму. Тобто найбільша частка мусульманських організацій була репрезентована в АР Крим, де серед найбілыш поширених релігійних напрямів іслам (29\%) займав друге місце після православ'я (42,7\%) [Звіт 2014].

Наразі в Україні діє вісім духовних управлінь мусульман, зокрема Духовне управління мусульман України (124 релігійні організації), Духовне управління мусульман України «УММА» (26), Духовний центр мусульман України (19), Духовне управління мусульман Автономної Республіки Крим (7), Духовний центр мусульман України «АХМЕДІЄ» (5), Духовне управління мусульман Криму (5), Духовний центр мусульман Криму (2), Релігійне управління незалежних мусульманських організацій України «Київський Муфтіят» (3), низка незалежних релігійних організацій мусульман (77) та шиїтські релігійні громади (9) [Звіт 2019b: 57-59].

Одним із актуальних питань у сфері державно-конфесійних відносин є питання забезпечення релігійних організацій культовими спорудами та питання повернення майна культового призначення, експропрійованого у свій час у релігійних організацій, зокрема і у мусульман, в період радянського режиму.

На початок 2019 року 36739 релігійних організацій використовують 29922 приміщень. Серед них 61\% типові культові споруди, а 39\% приміщення, пристосовані для молитовних потреб.

В контексті мусульманської спільноти то на початок 2019 року використовують 179 мечетей (12,3\%) та приміщень, пристосованих під молитовні $(87,7 \%)$. Таким чином, мусульманські організації забез- 
печені цими приміщеннями на 64,6\% [3віт 2019a]. Отже бачимо, що для мусульман в Україні актуальним є питання щодо побудови нових мечетей, зокрема і питання щодо виділення землі під забудову.

Актуальним в сфері державноконфесійних відносин залишається питання повернення релігійним організаціям колишніх культових споруд. На сьогодні в Україні, згідно з моніторингом, здійсненим Міністерством культури України спільно із Фондом державного майна, нараховується 188 культові споруди, які використовуються не за призначенням на $87 \quad 3$ них претендують релігійні організації. Це становить 0,88\% від загальної кількості повернутих і переданих культових споруд. Серед них мусульманські мечеті становлять 5,7\% (6 об'єктів).

Ці колишні культові споруди, які використовуються не за призначенням, знаходяться у АР Крим у м. Евпаторія (3), м. Ялта (1), м. Судак (1) та с. Піонерське, Сімферопольський р-н (1). Причинами неповернення цих об'єктів до 2014 року були: об'єкт приватизовано, об'єкт знаходиться в незадовільному/аварійному стані або в будівлі знаходяться державні/комунальні/ інші установи. Після 2014 року у зв'язку із анексією АР Крим ці питання відтерміновано на невизначений час, скільки територія Криму наразі не $є$ підконтрольною владним структурам України.

Необхідно зазначити, що законодавством України, окрім іншого, гарантовано право на міжнародні зв'язки та контакти релігійних організацій і віруючих. В контексті гарантування цього права релігійні організації також мають певні зобов'язання. Згідно зі статтею 24 Закону України «Про свободу совісті та релігійні організації» священнослужителі, релігійні проповідники, наставники, інші представники зарубіжних організацій, які $є$ іноземними громадянами і тимчасово перебувають в Україні, можуть займатися проповідуванням релігійних віровчень, виконанням релігійних обрядів чи іншою канонічною діяльністю лише в тих релігійних організаціях, за запрошенням яких вони прибули, i за офіційним погодженням 3 державним органом, який здійснив реєстрацію статуту (положення) відповідної релігійної організації [Закон 1991].

Таким чином, 3 питань релігійної діяльності в Україну найчастіше приїжджають із Сполучених Штатів Америки, країн Азї, Африки та Європи. Безпосередньо у 2018 році нараховувалося $2,4 \%$ запрошених іноземних священнослужителів мусульманськими організаціями.

Серед позитивних зрушень у сфері забезпечення свободи релігії в Україні на початку 2019 року Верховною Радою України було прийнято Закон України № 2673-VIII «Про внесення змін до деяких законів України (щодо підлеглості релігійних організацій та процедури державної реєстрації релігійних організацій зі статусом юридичної особи)» [Закон 2019]. В основу вказаного законопроекту були включені законотворчі напрацювання, розроблені представниками Департаменту у справах релігій та національностей Міністерства культури України спільно 3 Експертною радою 3 питань свободи та діяльності релігійних організацій, оскільки представники Мінкультури були залучені до робочої групи щодо підготовки тексту законопроекту. 
3 прийняттям вищезазначеного Закону було спрощено процедуру державної реєстрації релігійних організацій, оскільки функції 3 реєстрації статутів релігійних організацій та їх державної реєстрації як юридичної особи зосереджені в одному держоргані (відповідно в Міністерстві культури України та Раді міністрів АРК, обласних, Київській та Севастопольській міських держадміністрацій) в залежності від виду релігійної організації. Отже, стало можливим запровадження єдиного вікна 3 надання адміністративних послуг релігійним організаціям. Вказані зміни наразі полегшують процедуру реєстрації статутів всіх без винятку релігійних організацій.

Необхідно зазначити, що деякі мусульманські організації активно беруть участь у міжрелігійному та міжконфесійному дискурсі на інституційному рівні. Специфіка міжрелігійних, міжконфесійних об'єднань в Україні полягає в тому, що всі вони створювались за принципом спільної діяльності або ж $з$ метою реалізації проектів відповідного спрямування (видання та розповсюдження релігійної літератури; співпраця у військовій та пенітенціарній сфері тощо). На початок 2019 року в Україні діє дев'ять міжрелігійних та міжконфесійних інституційних об'єднань всеукраїнського значення.

Безпосередньо у два 3 них, а саме Всеукраїнську раду церков і релігійних організацій (заснована у 1996 році) та Всеукраїнську раду релігійних об'єднань (заснована у 2015 році) входять мусульманські організації, відповідно у ВРЦіРО Духовне управління мусульман України та у ВРPО - Духовне управління мусульман України «УММА». Сфери діяльності, в яких відбувається співпраця, стосуються освіти, капеланства, пенітенціарної системи, охорони здоров'я тощо.

У цілому діяльність міжрелігійних й міжконфесійних об'єднань в Україні можна охарактеризувати як плідну й активну, що поступово дає позитивні результати у вирішенні актуальних питань у сфері відносин між державними та релігійними інституціями.

Однак, релігійним спільнотам, зокрема і мусульманським організаціям, потрібно більш активно долучатися до плідного дискурсу для вирішення актуальних проблемних питань у сфері відносин між державою та релігійними організаціями. 


\section{Список літератури}

Брильов, Д.В. (2011). Іслам: історія, віровчення та культова практика. К.: Вид-во НПУ ім. М.П. Драгоманова. 142 с.

Закон України «Про свободу совісті та релігійні організації» (1991). Відомості Верховної Ради УРСР, № 25, ст.283). Отримано 3: https:/ / zakon.rada.gov.ua/laws/show/987-12. Закон України № 2673-VIII «Про внесення змін до деяких законів України (щодо підлеглості релігійних організацій та процедури державної реєстрації релігійних організацій зі статусом юридичної особи)» (2019). Відомості Верховної Ради, № 6, ст.40). Отримано 3: https://zakon.rada.gov.ua/laws/show/2673-19 звіт про забезпеченість иееков і релігійних організаціий України культовими будівлями та приміщеннями, пристосованими під молитовні станом на 1 січня 2019 року (Форма №2) (2019а). Київ: б.в. 131 с.

Звіт про мережу изерков і релігійних організацій в Україні станом на 1 січня 2014 року (Форма №1) (2014). Київ: б.в. 58 с.

Звіт про мережу цеекков і релігійних організацій в Україні станом на 1 січня 2019 року (Форма №1) (2019b). Київ: б.в. 42 с.

Ісламська держава: генезис і нові тренди (2015). Під редакцією Салаха 3., Ауліна О.А. Львів.:

Видавництво «Компанія «Манускріпт». 152 с.

Ісмагілов, С.Я., Якубович, М.М. Ісламознавство: навчальний посібник (2018). Вінниця: ТОВ “Нілан ЛТД". 236 с.

Мусульманська спільнота Украӥни: інституалізація і розвиток (2016). Під заг. ред. Ауліна О.А. Вінниця: Консоль. 400 с. Особливості релігійного і изерковно-релігійного самовизначення українських громадян: тенденції 2010-2018 рр. (інформаційні матеріали) (2018). Київ: Razumkov centre. 78 c.

Якубович, М. Від Майдану до АТО: українсъкі мусульмани в умовах військово-політичної кризи (2013-2016) (2017). Вінниця: Нілан. 156 с.
Features of Religious and Church-Religious SelfDetermination of Ukrainian Citizens: Trends 20102018 (Information Materials) (2018). Kyiv:

Razumkov Center. 78 c.

Islamic State: Genesis and New Trends (2015). Edited by Salah Z., Aulin OA Lviv: Manuscript Company Publishing House. 152 p.

Ismagilov, S.Ya., Yakubovich, M.M. Islamic Studies: A Tutorial (2018). Vinnytsia: Nilan LTD. 236 p. Law of Ukraine "On Freedom of Conscience and Religious Organizations" (1991). Information of the Verkhovna Rada of the USSR, No. 25, Art.

Retrieved from: https:/ / zakon.rada.gov.ua/laws/show/987-12. Law of Ukraine No. 2673-VIII «On Amendments to Certain Laws of Ukraine (Concerning Jurisdiction of Religious Organizations and Procedure of State Regis-tration of Religious Organizations with Legal Entity Status)» (2019). Information of the Verkhovna Rada, No. 6, Article 40). Retrieved from:

https://zakon.rada.gov.ua/laws/show/2673-19 Report on the Network of Churches and Religious Organizations in Ukraine as of January 1, 2014 (Form \# 1) (2014). Kyiv: b.v. 58 p.

Report on the Network of Churches and Religious Organizations in Ukraine as of January 1, 2019 (Form \# 1) (2019b). Kyiv: b.v. 42 p.

Report on the Provision of Churches and Religious Organizations of Ukraine with Religious Buildings and Premises Adapted to Prayer as of January 1, 2019 (Form \# 2) (2019a). Kyiv: b.v. 131 p.

The Muslim Community of Ukraine: Institutionalization and Development (2016). Under the head. ed. Aulin OA Vinnytsia: Console. $400 \mathrm{sec}$. Yakubovich, M. From the Maidan to the ATO: Ukrainian Muslims in the Conditions of MilitaryPolitical Crisis (2013-2016) (2017). Vinnytsia: Nilan. $156 \mathrm{p}$.

\section{References}

Brylov, D.V. (2011). Islam: History, Doctrine, and Worship. K .: Publishing house of NPU them. M.P. Drahomanov. $142 \mathrm{p}$. 